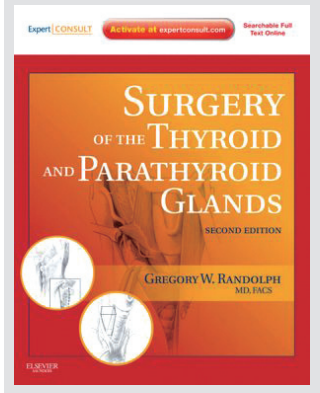

\title{
Surgery of the Thyroid and Parathyroid Glands, Second Edition
}

\author{
Gregory W. Randolph
}

Surgery of the Thyroid and Parathyroid Glands, Second Edition(ISBN 978-1-4377-2227-7)는 Harvard Medical School 의 이비인후과 부교수인 Gregory W. Randolph가 대표 저자로 참여하고 전 세계에서 활동하고 있는 약 75명의 저명한 갑상선 외과 전문의, 갑상선 내과 전문의, 방사선과 전문의, 병리 전문의, 핵의학 전문의, 기초 과학자들이 모여 2003년 초판 이후 10년 만에 2판을 출간했다. 이미 초판에서 갑상선 및 부갑상선 질환에 대한 다양한 병태생리, 수술 해부학, 술 전 및 술 후 검사법, 최신 수술 방법 등을 소개한 바 있으며, 이번 2판에서는 근래에 보고되고 있는 술 전 국소화 방법(preoperative localization), 유 전자 분석(genetic analysis), 반회 후두신경 감시(recurrent laryngeal nerve monitoring), 술 중 부갑상선 호르몬 측정(intraoperative parathyroid hormone analysis), 최소 침습 수술법(minimally invasive approaches) 등 다양한 분야를 독자에게 이해하기 쉽게 설명하고 있다. 초판과의 또 다른 차이점은 온라인 비디오 강의를 통해 저명한 술자들의 다양한 수술 술기를 볼 수 있다는 것이다. 이를 통해 일반적인 갑상선 외과 교과서에는 나와있지 않은 저자들의 pitfall이나 수술 tip 등을 추가하여 갑상선 및 부갑상선 수술을 시작하는 초심자들에게 많은 도움을 준다.

복잡하고 어렵기만 한 갑상선, 부갑상선 수술을 친절하고 이해하기 쉽게 자세히 기술한 이 책을 갑상선 수술에 관심 있는 전 공의나 강사 분들에게 추천하고 싶다.

대한이비인후과학회 간행위원회 